\title{
St Kilda
}

\section{Bronwen Manger}

This place,

gaudy as an open wound, wears its weather beaten halo

askew.

I am regurgitated out

onto the footpath

by a mouth that gapes night

and day, frozen somewhere

between a grin and

a bite.

Shadeless, limbless trees

strain into a stricken sky. Fevered

cafes sweat people with brass skin

and concrete eyes.

Saturday night distends the streets

and a clawed hunger stamps

and struggles beneath

my ribcage.

I have trudged in the rain,

I have cried in the dark,

I have searched in the sea, 
and slumped in the restaurants

eating pins and needles and

despair.

But I found one night

once, years ago we

laughed immortal and absurd,

disbelieving and joyful in some vineless

Vineyard.

We laughed;

and St Kilda,

I forgive everything. 